\title{
$\underline{\text { VoIP Regulation in Latin America }}$
}

\author{
Juan Rendón \\ Department of Information and Communication Technologies \\ Pompeu Fabra University, Barcelona, Spain \\ juan.rendon@upf.edu \\ Martha García-Murillo \\ School of Information Studies, Syracuse University \\ United States \\ mgarciam@syr.edu \\ Ana Villegas and Federico Kuhlmann \\ Digital Systems Department, ITAM University \\ Mexico DF, Mexico \\ aevillegasc@hotmail.com; kuhlmann@itam.mx
}

\begin{abstract}
:
Voice over IP (VoIP) is a disruptive technology that can be considered a menace to current circuit-switched telephony operators. This paper studies the regulation that affects VoIP technology in Latin America. In order to carry out the analysis, the "motibility" framework developed by Anthony, Roth and Christensen was applied. In all the countries studied it was found that the incumbent operators do not have the motivation to deploy VoIP services because they are already offering voice services by means of their deployed circuit-switched telephony network. The paper mentions a few recommendations that could be helpful to motivate operators to deploy this technology.
\end{abstract}

Keywords: VoIP, Regulation, Latin America

Paper to be presented at the $35^{\text {th }}$ Research Conference on Communication, Information and Internet Policy (TPRC 2007), September 28-30, 2007, Arlington, Virginia, USA 


\section{Introduction}

The way communications take place in our world has dramatically changed throughout the years. Lately, IP networks have been growing and settling down, which enables companies and households to use the Voice over IP (VoIP) technology. At first, VoIP had many disadvantages, such as voice quality, security, and availability problems, which made it unattractive for residential and business users. Nowadays, VoIP is gaining a stable position in many countries, which leads to think it is important to voice and data convergence. People in many countries have started looking at VoIP as an alternative to traditional telephony services. For companies, it represents saving inner communication costs and increased market competition. Another characteristic of this technology is that it can threaten the incumbent by allowing a different operator to enter the market and get positioned in it. In Latin America, the incumbents dominate the communications market, and VoIP could challenge their business models by allowing users to have options instead of having to deal with a monopolistic figure. There are several VoIP operators that offer services in different countries in Latin America, although the service is not very common yet.

There have been a few studies about VoIP in Latin America. For example, (Swain, 2006) presents regulatory scenarios in different countries and describes how operators (both established and new) could face challenges and opportunities.

The objective of this paper is to analyze VoIP regulation in Latin America. The following five countries were studied: Argentina, Brazil, Chile, Mexico and Peru. In order to understand the current position of the incumbent operators regarding the VoIP technology a framework developed by Anthony, Roth and Christensen (Anthony, 2002) was applied. This framework helps categorize each country according to its characteristics and suggests regulatory actions that would help incumbents to reach a point where they are willing and able to provide VoIP services.

The paper is organized as follows: Section 2 describes the Analytical Framework used, whereas Section 3 contains the country cases. In this latter section an analysis of the countries' characteristics in terms of VoIP is presented, making a differentiation between ability and motivation, which are the main aspects to take into consideration for the analysis. Afterwards comes the location of each country in the model's framework. Finally, Section 4 addresses the conclusions and recommendations.

\section{Analytical framework}

Since the late 1990s it was recognized that the IP protocol would be the dominant technology for networks (Mueller, 1999). There are many reasons why this is the case. First and well known is the considerable price difference that exists between telephony via traditional carriers and telephony using a VoIP provider. This is evident for both residential users who can save upwards of $75 \%$ on their long distance calls in addition to the added value added services such as call conferencing and caller ID that come bundled with a package. Second, there are business benefits for the ability that this technology gives at the moment of integrating data and voice networks (Thomsen \& Jani, 2000). The success of this technology, as described by Werbach (Werbach, 
2005), goes beyond these two elements: companies can use VoIP to improve productivity, improve customer service, built their brand names and support strategic planning operations.

Today, in spite of the great progress that this technology has made, there are still important deficiencies that have to do primarily with quality of the voice reception. This will nonetheless become a problem of the past. Efforts are being made to improve QoS for this service (Takahashi \& Yoshino, 2004). The enormous progress and awareness of the capabilities of this technology were the drivers of the growth in the number of subscribers in all the different modalities of the service. For example, Skype, a service that allows people to make calls for free using one's computers, made 7 million dollars in 2004 (Weyer, 2005) and it has been projected that by 2008 there will be 18 million subscribers just in the US (VoIP Subscribers (Fast Facts)(Brief Article), 2005).

VoIP, in all its modes, is a technology that can be considered disruptive. A disruptive innovation can be described as a technology, product or service that comes to dominate the market and eventually replaces the existing leaders (Christensen, 2000). One of the significant characteristics of a disruptive innovation is that often these technologies exhibit inferior features and quality which may in turn lead to prices that are lower than those of products or services currently in the market. Because of this they are not appealing to the mass market, and existing players are often unable to respond with a similar offering; they don't want to jeopardize their revenue stream or customers with an unproven technology.

According to Scott and Christensen, for an innovation to be considered disruptive, it needs to pass several tests that correspond to a series of questions (Anthony, 2002). First, the innovation has to have an opportunity to grow outside of the mainstream market and establish a "beachhead in a niche of the incumbent's market. Second, the innovation has to be able to improve its physical limitations and its economics to be able to attract customers; and third, the incumbent should find it difficult to respond. Based on these three characteristics Scott, Roth and Christensen define a disruption as a "technology or business model that an incumbent is unable to mount an effective competitive response against resulting in a loss of significant market share and dramatic changes in the competitive landscape of a market or industry” (Anthony, 2002).

At the time Christensen wrote his book he assumed that a given innovation will only affect a single industry. This is clear by the examples that are mentioned in the book such as disk drives and mainframes to PC, for example. However in the advent of convergence the impact of one innovation is no longer constrained to one industry. We are now seeing how one innovation can have different effects on the different industries that currently dominate the market. VoIP is one of those technologies. While the traditional telecommunications operators will not be able to respond without loosing at least significant revenues, there are other large players in related markets for which this technology is an opportunity. We are of course referring to the cable TV and for some countries the Electric Utility Companies. In addition to these two there are also entrepreneurs who, taking advantage of the broadband infrastructures already in place, are offering software communication products like Skype to provide voice type services.

This technology has such great impact on the industry that regulators are now facing the great difficulty of trying to determine if they need to regulate it, and if so, how. There are several factors that make regulating this technology particularly difficult. First it affects large players 
with opposing views on the issue. This means that regulators or policy makers will face significant pressure from the most affected players to try to reduce or delay the impact. As stated by Afhua (Afuah \& Tucci, 2003), companies that face these threats will try to defend their position by delaying the use of the technology. In addition, because this technology offers basically the same product as traditional telephony which is heavily regulated, these entities are now facing such considerable challenges that they are almost being forced to rewrite their telecommunications laws (Vaida, 2004).

Given the difficulties that regulators face, there is thus a need to find tools that can help these decision makers to determine the best way to regulate the service or more appropriately a converging set of industries. Recently, a paper by Anthony, Roth and Christensen attempted to do just that (Anthony, 2002). In this paper we use such a framework to help understand the decisions that regulators are making with respect to Internet telephony in their countries and provide some greater detail to the external forces that they identify, but for which they provide little detail.

The framework, which they quaintly named "motibility", has two forces: motivation and ability, thus the name. In this section we present the original motibility framework but expand on the role of the external factors to help us understand how regulators can use those circumstances to try to modify the behaviour of the incumbent players to embrace and improve the innovation. The motibility framework is presented as a matrix that has two axis (see Figure 1). The horizontal axis represents the ability of this company/industry and whether it has the resources to move towards the optimal business conditions. The vertical axis presents the motivation of these players to adopt or not a technology. Based on these two elements Scott, Roth and Christensen identify four scenarios.

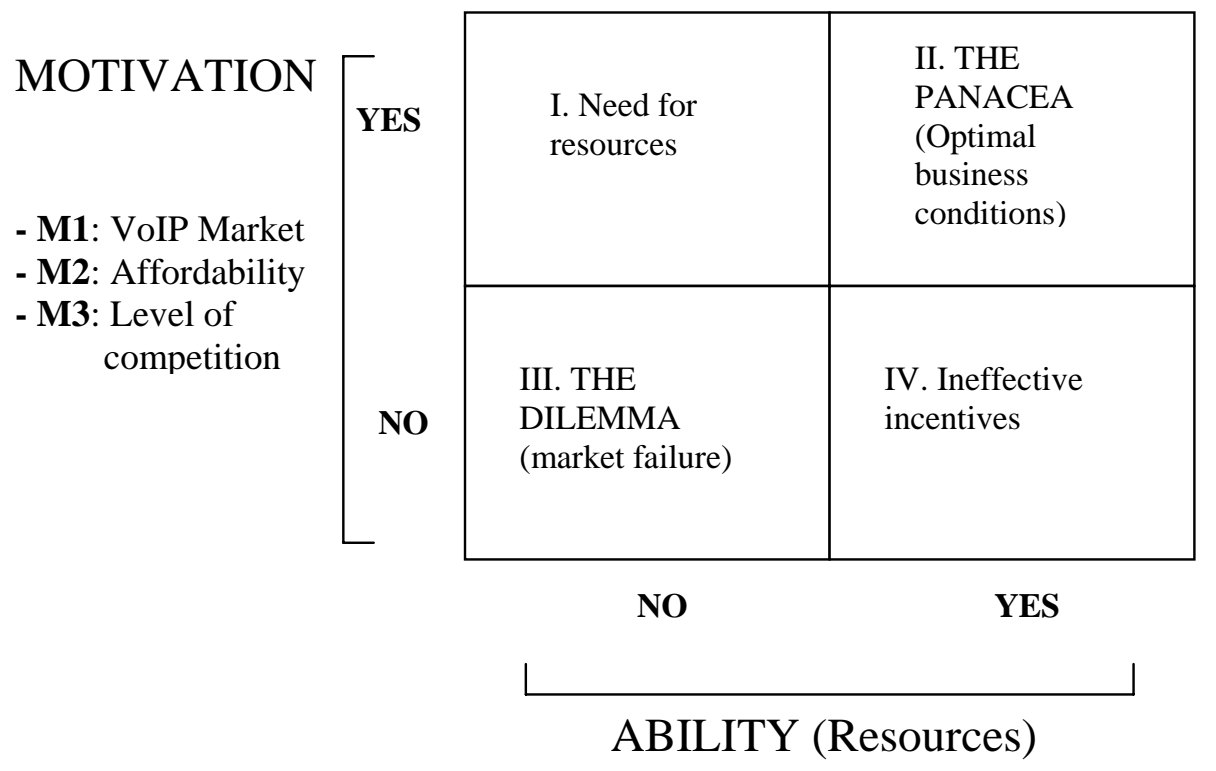

- A1: VoIP Regulatory Framework

- A2: Universal Service

- A3: Numbering and Emergency Numbers

- A4: Infrastructure

Figure 1: Motibility framework 
The ideal scenario, which they called the panacea, represents the optimal market conditions where there is great dynamism, innovation is taking place, competition is healthy and the industry in general is evolving profitably. It is clear that in the context of VoIP there are players that are in the panacea box such as those new entrants like Skype, Vonage and even Cable operators for which this technology is an extension of their business.

The worst scenario, the dilemma, arises when a company/industry does not have the resources or the motivation to adopt the new technology. This is sadly the situation of many incumbent operators in Latin America, particularly those that are still government owned. It will be particularly difficult for regulators under those circumstances to be able to make a decision given that they do not want to adopt a technology which will significantly reduced public revenues.

Many private incumbent telecommunications operators in the world fall into the ineffective incentives quadrant, where they have the resources but do not have the incentives to adopt VoIP. These are carriers that are being extremely cautions about the way they implement IP. It is clear that most of them already use it for their long haul transmissions because it makes the use of the network much more efficient. These operators find it difficult to respond to the pure VoIP providers because they have much to loose if they do so.

The last quadrant, the need for resources, represents those companies that would like to be able to adopt the technology but lack the resources to be able to do it. In the case of VoIP we will see that obvious new entrants are electrical power companies, whose networks reach every house and business. In this case the resources are in the form of other alternative technologies that would help them to overcome the power emissions problem that they face if they try to use power lines to transmit data.

For the purpose of this analysis the motibility framework will be focus on traditional incumbent telecommunications operators given that it is this sector for which regulation needs to be defined.

The external factors associated with the motivation elements of the framework relate to the size of the VoIP market, the demand conditions of the potential users and the level of competition.

If the market is large and even if it loses revenue, the size of the market and the opportunities that can be opened with the new technology can help to overcome the loss of revenue. With few exceptions, Latin America is a relatively depressed market. This is due to the fact that the income per capita and the affordability levels are low. For some countries like Mexico and Brazil this weakness can be overcome through volume but for many other Latin America countries this is not the case.

Demand can be a limiting or a fostering factor. If a market has an abundance of technologically sophisticated users, the traditional carrier may be forced/motivated to introduce the new technology. Unfortunately for most of the region there is limited access to computers which make large segments of their population technologically or digitally illiterate. 
The factors that affect ability are the VoIP Regulatory Framework and elements such as Universal Service, Numbering and Emergency Numbers and Infrastructure related to VoIP.

There are many companies that would like to be able to make the transition to IP and offer triple play services. For many of these companies the main problem is the large amount of resources that will be necessary to upgrade or make adjustments to their current networks to be able to offer these services. This is mostly the case of cable TV, electrical power and potentially satellite operators which already offer video and data.

In this case the regulation that affects motivation relates to the type of norms that prevent or forces a carrier to do something specifically. For example, carriers were forced to unbundle their infrastructure. Under such incentive many operators had little incentive to upgrade their networks and offer more sophisticated or advanced services. In many countries like Argentina, for example, the telecommunications carriers are not allowed to enter the video distribution business. This could then make them less cooperative towards its competitors and delay the adoption of IP in theirs and other's network.

There are multiple standards that need to be established for some of the players to be able to enter the market to provide VoIP. First for mobile carriers greater spectrum is necessary and these along with the traditional wireline counterparts have little incentive to offer VoIP. Electrical power companies need to find a technology that solves the problem of power emissions and although not crucial for these players an integration between the traditional phone numbering system and the internet address domain name would further the capabilities of this technology and the potential attraction of more players.

The existing information infrastructure is critical for some VoIP providers. In a country that is dominated by narrow band networks, VoIP is an impossible offer. Given the time sensitivity of voice only broadband networks are able to carry this service. This is thus a key resource for competitors. Similarly, for some type of VoIP offerings the spread of computers is another key resource. While it is true that there are still many households in Latin America that do not have a computer it is also true that more and more countries have internet cafés or telecenters where voice communication is possible.

Finally, as can be seen from the picture, regulation is listed as both a motivation and a facilitator. In this case the relevant regulations are those that affect the resources of the incumbents or of the competitors. Access to numbers is a key resource for VoIP providers, access to other carrier networks is another key resource and spectrum is also an element that would affect the entrance of competitors to the wireless space.

In the next section we describe the circumstances that prevail in each of five countries and the type of responses that they are adopting to move the industry towards the panacea. 


\section{Country Cases}

This section analyses five countries in Latin America within the context of the theoretical framework. Because VoIP has the greatest impact on the fixed line operators, we focus on that segment of the market for this analysis.

\subsection{Argentina}

The Communications Secretary (SECOM), the National Communications Commission (CNC) and the Consumer Defence Secretary are the three organisms that regulate telephone and Internet services in Argentina. The SECOM is in charge of helping the Executive power to propose, elaborate and establish telecommunication policies, as well as proposing their regulatory framework. It also establishes competition rules and it defines user rights and duties. Its goal is to study and update policies, according to what is happening around the world.

The CNC is the regulatory agency in charge of controlling the spectrum, telecommunications and postal service, and applying sanctions when the regulatory framework gets violated. It is also in charge of helping the SECOM to develop and update telecommunication plans, and general rules for each service. This commission represents Argentina in international events; receives instructions and works based on the SECOM, although it is a decentralized organism. It is subdivided into sections in charge of Control, Regulatory Aspects, Postal Service, Engineering, Administrative Aspects and International Relations.

\subsubsection{Ability}

A1.- VoIP Regulatory Framework: Regulation in Argentina considers IP as a mere way to offer telecommunication services, such as telephony in the form of VoIP, thus there are no legal barriers that impede market access or any plans to regulate different types of the service. Any provider is free to offer telecommunication services with different technologies and network architectures, based on the network neutrality principle. It is also considered inconvenient to limit VoIP services to those who run over the IP network, without connection to the PSTN (Comunicaciones). A specific resolution states that VoIP services are free to compete in the market, and there are no efforts to regulate or impose restrictions on it (Comisión Nacional de Comunicaciones, 2000).

Any operator who wants to offer VoIP needs a Unique License (Comisión Nacional de Comunicaciones) for Telecommunications Services, which covers all telecommunications services, independently of the technology and network infrastructure used. Unique licenses are granted on demand, without time limit, enabling providers to offer any kind of telecommunication service, whether it is national, international, fixed, mobile, etc. It does not guarantee, however, availability of means necessary to provide each service. Internet Service Providers (ISPs) need a value added service license to operate, and have to pay interconnection rates to local telephone companies. It is specified in regulations that there is freedom between the parties to agree on the interconnection fees. Service providers have to negotiate their interconnection agreements with the incumbent operators. Neither the CNC nor the SECOM get 
in the way of these discussions. The foreign investment policy is liberal and there are no distinctions between local and foreign companies.

According to the network neutrality principle, there are no regulated technological standards or protocols for VoIP.

A2.- Universal Service: According to the 764/2000 Decree (Comisión Nacional de Comunicaciones, 2000), any telecommunication service provider has to contribute to the Universal Service Fund (Fondo Fiduciario del Servicio Universal, FFSU) with 1\% of their revenues (International Telecommunication Union, 2006). A provider offering any kind of telephony services in areas where telephone density is less than $15 \%$ is not obliged to contribute with USF fees, and incumbents have a single obligation over basic telephony services.

A3.- Numbering and Emergency Numbers: There is no specific numbering plan for VoIP. Some companies such as DIGIVoice offer the DID (Direct Inward Dialing) service, which is a PSTN number. Every call received in this number will be considered local and redirected to the user, even if the user is in other parts of the world. Since VoIP services may use traditional numbering through DID, they must fulfill the requirements of a communication service, providing emergency service numbers, guides, free customer service number and QoS, among others. In practice, not every provider meets the requirements.

A4.- Infrastructure: In 2005 there were 227 telephone lines, 177 Internet users and 83 personal computers per 1000 people (World Bank, 2005).

Between March and June, Broadband Internet access increased 16.9\%, reaching 1,219,497 lines (Comisión Nacional de Comunicaciones). 75.13\% of the total Argentinean households have a telephone, and PC market was estimated in 5 millions, while broadband access reached 1.5 millions. According to a study (Cisco Systems, 2006) performed by IDC Argentina and sponsored by Cisco Systems in 2006, annual growth of Internet connections was 66.2\%, with 1,583,713 lines. Approximately 1.58 million homes have a broadband connection. ADSL technology grew around 76\%. The Cisco Broadband Barometer indicates Argentina had a 2.7\% broadband penetration in its total population in March, 2006.

\subsubsection{Motivation}

M1.- VoIP Market: In Argentina, Telefónica Argentina and Telecom Argentina are the regional incumbents. As an example of companies that provide VoIP services, the following cases are offered: IPlan is one of the major VoIP providers in Argentina, offering services to more than 7000 enterprises. Its service, called Proximo, requires only downloading software to start making international calls. Calls between Proximo users are free, as every user gets a free IP telephone number when they register for the free version. There are different plans that enable calls to and from the PSTN. Receiving calls is free; if the caller gets a busy signal, the call will be redirected to voice mail. Proximo offers Caller ID, number portability and the ability to choose a phone number from one of the cities where IPlan is present. Services from other companies include giving foreign users a local telephone number, thus paying less for each call. There are also users 
of services like Skype or MSN, which talk to other service users without having to pay at all. Prepaid card users also get cheap rates to make phone calls.

Another important provider of VoIP is DIGIVoice, which provides open services and is in alliance with Heilsberg, S.A., in order to operate in Argentina. They expect, for 2008, that 8 of each 10 calls will be made using VoIP. DIGIVoice has a CNC license to operate, which enables them to offer telephony service by means of IP. Since the CNC determined that the technology used to offer telecommunication services is independent to providing those services, DIGIVoice is not incurring in illegal activities. They have different formats, which are calling from a conventional phone, from an IP phone or from a softphone, to national or international phones, whether fixed or mobile. The first format needs an adapter to reach the Internet and to reach another conventional phone. They don't offer broadband Internet connections but do offer free and unlimited calls between customers, compatibility, pre-paid plans, technical support the entire year, caller-ID, voicemail, call waiting and virtual numbering.

M2.- Affordability: According to a study (INDEC, 2007), on the first quarter of 2007 average family income per capita in the tenth decile (\$2201) was thirty times bigger than the one from decile one (\$73). A survey done by INDEC shows that in 2005 the average household monthly expense was $\$ 1242$, and that $15.2 \%$ of the total family expense was destined to transport and communications. According to the World Bank, the Information and Communication Technology (ICT) expenditure in 2005 was 7.1 (\% of Gross Domestic Product) (World Bank, 2005).

M3.- Level of competition: Table 1 shows a comparison of the telephony tariffs in Argentina between the incumbent operator Telefónica Argentina and the VoIP provider DIGIVoice.

\begin{tabular}{|l|c|c|}
\hline & DIGIVoice (USD) & Telefónica Argentina (USD) \\
\hline Local calls (per minute) & 0.0250 & $\begin{array}{c}0.178230 \text { (normal) } \\
0.146404 \text { (reduced) }\end{array}$ \\
\hline Minute to Rome, Italy & 0.0325 & 0.063653 \\
\hline Minute to Lima, Peru & 0.0450 & 0.063653 \\
\hline
\end{tabular}

Table 1: Telephony Tariffs in Argentina

Because VoIP is cheaper there is a high probability that households will want to switch to this service. If this is the case the technology cannibalizes current services offered through the fixed infrastructure and unless these carriers find additional value/revenue from VoIP they may feel reluctant to upgrade their networks to IP and pass the savings to their customers

\subsubsection{Analysis}

The incumbents are comfortable offering services they have been offering for years. Most of the conditions necessary to offer VoIP services already exist, but the main cause to prevent it from happening is the lack of motivation. The incumbents can use their already deployed networks and because of network neutrality they can take advantage of the license they already have to operate. They have no need of getting into agreements to interconnect and must not follow any specific standard. It can be concluded that incumbents are located in the fourth quadrant of the motibility framework, looking for the profit that will motivate them to offer VoIP. 
The governmental institutions do not forbid the deployment of VoIP but, on the other hand, they do nothing special to promote the VoIP technology.

\subsection{Brazil}

In Brazil, the regulating organism is the National Telecommunication Agency (ANATEL). The communications Minister is in charge of making public policies in order to provide democratic and universal access to every service. Along with the Telecommunications Secretariat, it establishes policies, objectives, goals and rules, as well as supervises ANATEL's activities. ANATEL is able to implement national telecommunication policies, install or eliminate services in public regime, handle radio frequency spectrum, solve conflicts between service providers and protect consumers' rights and duties, establishing prices for each service (as long as it is public). Every rule ANATEL elaborates has to be justified and be submitted to public consultation. There is a telecommunication control fund, called FISTEL, which is in charge of the agency's financial independence. There is also a Board integrated by the Congress, a representative of the Executive and society in general.

\subsubsection{Ability}

A1.- VoIP Regulatory Framework: Brazil has no specific regulations or legislation for VoIP services although it is not illegal to provide them. A company might be considered a Telecommunication Service Provider (TSP) or a Value-Added Service Provider (VASP), based on the Brazilian General Telecommunications Law (July, 1997). The difference is that a VAS is not considered a telecommunication service but an activity that adds new capabilities to that service, such as access, storage, presentation, movement or retrieval of information. Providers of VAS are labeled as users of a telecommunication service with rights and duties inherent to that status.

The Telecommunications law and the category each company falls into, are independent of technology; differentiation is rather associated with the transmission, emission or reception concept. To enter the market, an operator needs a Multimedia Communication Services (SCM) License, which allows the transmission, emission and reception of multimedia information and is not limited to voice services. As technology has nothing to do with VoIP services, TSPs are subject to traditional telephony obligations.

ANATEL divides VoIP into the following three classes that determine whether a service license is needed to operate, along with the operator's rights and obligations:

\section{Class I}

- VoIP supplied via Internet, with specific audio software installed on a PC that serves for communication between computers.

- There is limited access to users who own such programs.

- It is considered a value-added service, no license needed.

* Class II

- Restricted VoIP, supplied via corporate network or within a telecommunication service provider's network. 
- It is considered a telecommunication service and a multimedia license is needed, Class III whether it is for personal use or to provide service to other people.

- Unrestricted voice service, interconnected to the PSTN.

- Service equivalent to telecommunications, whereby the provider must have a full operator license. Authorization is essential. Users must be allowed to select alternative providers for national and international long distance services.

A2.- Universal Service: If the operator has a license, it is obliged to contribute to FUST (Fundo de Universalização dos Serviços de Telecomunicações), FISTEL (Fundo de Fiscalização das Telecomunicações) and FUNTTEL (Fundo para o Desenvolvimento Tecnológico das Telecomunicações), the Brazilian universal service funds. FUST provides resources that cover costs of generating universal services. FISTEL is the telecommunications prosecution fund, and it manages the money collected from telecommunication service providers. FUNTTEL is a fund for technological development, and is in charge of stimulating technological innovation by educating and facilitating resources to small-sized operators, in order to generate competition. Class II VoIP is not considered a replacement for traditional telephony, so providers are not required to contribute.

A3.- Numbering and Emergency Numbers: Phone numbers are being matched to VoIP service lines. ANATEL is analyzing the plans that every fixed telephony service concessionaires that pretend to use VoIP have. At the same time, regulators are studying the numbering plan for the Multimedia Communication Service.

VoIP operators are not obliged to offer emergency services.

A4.- Infrastructure: The trend is for VoIP services to grow, especially with projects that plan to deploy the WiMAX technology, although a survey made by NIC.br, showed that more than half of Brazil's population has no Internet access, with only 14\% of Brazilian homes having that privilege (CGI, 2006). Most of them, around 25\%, live in the southern part of the country, while on the northern region only $8.5 \%$ of the houses have an Internet connection. It is noticeable that, according to this survey, about $56 \%$ of the Brazilians has never used a computer, and that $65 \%$ of the entire population has never entered the Internet. According to a study made by the Yankee Group, broadband market will grow and by the end of 2007, 5\% of the country will have broadband service.

\subsubsection{Motivation}

M1.- VoIP Market: Many telephony service enterprises offer VoIP because it is profitable. Two of the incumbent operators, Telemar and BrasilTelecom, are currently offering VoIP residential services. As other telecom companies started offering VoIP services, specially in the longdistance market, the incumbent operators were motivated to enter the VoIP market. In terms of reality, Brazil has the largest number of VoIP users in Latin America, since it has the largest number of Internet users in Latin America. It is one of the top five countries in the world communicating through Skype. A study made by the Yankee Group shows that one of each four brazilian corporations uses VoIP (Trope, 2005). 
If a foreign company wants to offer VoIP in Brazil, it can a) open a company in Brazil and get a license from ANATEL, or b) form a partnership with a Brazilian company that has a license. There are US companies offering VoIP services. Skype has partnered with Transit Telecom, which is an operator authorized to offer voice services to the corporate market. Telefónica provides VoIP as a strategy to promote broadband services.

The incumbent operator BrasilTelecom is the first Brazilian telecom attending every market demand with convergent solutions for fixed and mobile telephony, data, national and international long distance calls and broadband Internet access. After a year of operation, it surpassed 1.7 million mobile customers, earning the first place between its competitors and reaching $15 \%$ of corporative market, which is the most profitable segment of the mobile market.

BrasilTelecom started offering VoIPFone (BrasilTelecom) the last months of 2005. VoIPFone is a virtual phone that can be used from any part of the world to make or receive phone calls, which will be charged as if the user was in its hometown, or the city the VoIPFone number belongs to. The company offers two ways to receive the service, one is using a Softphone (software for the computer, simulating a telephone) and the other one is buying an adapter for the conventional telephone, so it can work as a VoIP phone. Amongst the services offered when using the Softphone are: sending online messages to other VoIPFone users, ability to see who is online, automatic redial, caller ID and recording calls. It also comes with different "smart" services without charge: Call waiting, Caller ID, Follow me, Virtual Secretary and Softphone conference.

M2.- Affordability: According to CEPAL's 2005 information (CEPAL, 2006), the income distribution in Brazilian homes is as shown in Table 2.

\begin{tabular}{|l|l|l|l|}
\hline Poorer (40\%) & Poor (30\%) & Rich (20\%) & Richer (10\%) \\
\hline $11.9 \%$ of total income & $18.5 \%$ of total income & $25 \%$ of total income & $44.6 \%$ of total income \\
\hline
\end{tabular}

Table 2: Source: Programa social de América Latina 2006, Pobreza y distribución del ingreso, CEPAL

According to the World Bank, the ICT expenditure in 2005 was 7.8 (\% of Gross Domestic Product) (World Bank, 2005).

\section{M3.- Level of competition:}

Table 3 shows a comparison of the telephone tariffs in Brazil between the operators Telemar, Telefónica and Brasil Telecom.

\begin{tabular}{|l|c|c|c|}
\hline & Telemar (R\$) & Telefónica (R\$) & Brasil Telecom (R\$) \\
\hline Local calls (per minute) & 0.3100 & 0.14672 & 0.1962 \\
\hline Minute to Rome, Italy & 0.3100 & 2.08251 & 1.80798 \\
\hline Minute to Lima, Peru & 0.9841 & 2.78450 & 2.22845 \\
\hline
\end{tabular}

Table 3: Telephony Tariffs in Brazil

Calls a customer originates are only be tariffed when they last more than three seconds. Calls a customer receives from fixed lines (calls he will have to pay for) will be tariffed only after 
receiving authorization for completing it and if its duration is superior to six seconds. There is no monthly fee for calling cell phones, since they are tariffed on a minute basis. Calls originated to a cell phone are tariffed only if the call lasts more than three seconds. Received calls request authorization for reception (in case the call is being charged to the receiver) and are tariffed only if they last more than six seconds.

\subsubsection{Analysis}

Two of the incumbents, BrasilTelecom and Telemar, offer VoIP services. Even though there is no service regulation, the companies have an operating license and meet the requirements of traditional telephony, such as contributing to service universalization. Some incumbents are offering VoIP services at both residential and business levels.

In Brazil there is a clear VoIP services definition, distinguishing amongst those between two computers, those restricted to private networks and those interconnecting with the traditional telephony network, either with a generating or an ending call. A license is needed for any of the last two classes.

Even though a few incumbent operators offer VoIP services, they still do not seem too enthusiastic at the moment of deploying this technology. Therefore, the incumbent operators are not in the panacea quadrant and are in the fourth quadrant of the motibility framework.

\subsection{Chile}

Chile's regulating organism is the Telecommunications Subsecretary, SUBTEL, which depends on the Telecommunications and Transports Ministry. There is a Telecommunications Sub secretary, head of the entire institution, as well as subdivisions that take care of management, legal matters, regulation, concessions and information access. This organism controls, promotes and develops Chile's telecommunications, in order to transform information technologies and telecommunications into economic and social benefits for the country.

\subsubsection{Ability}

\section{A1.- VoIP Regulatory Framework:}

In 2004, SUBTEL launched its first public consultation about VoIP services and regulation. In 2006 SUBTEL was planning a flexible VoIP regulatory framework that allows the offer of voice telecommunication services through the Internet, as well as providing users with telephone numbers, QoS and other advantages. In December 2006, SUBTEL launched a public consultation (SUBTEL, 2006) about this regulatory framework, identifying every aspect to be included in the regulation. The main points stated in the consultation were the following:

- VoIP service providers must guarantee service availability and quality to all users, informing them about minimum requirements to meet the offered standards.

- Only IP to PSTN (or vice versa) communications will be subject to regulation. 
- Connections between the PSTN and IP will be guaranteed. Interconnection fees will be covered by the VoIP service provider.

- Users will freely decide which long distance carrier to hire.

- VoIP users will be able to enable or suspend complementary services connected to PSTN concessionaries, as well as to block access to mobile and national or international long distance calls.

- Users that want to subscribe to VoIP services will need to acquire Internet access on their own.

- VoIP providers must grant free access to PSTN emergency services.

- SUBTEL will assign numbering to ensure communication between the PSTN and VoIP users.

Since VoIP will be considered a public telecommunication service, it will need a concession and will be subject to interconnection, tariffication and numbering norms (Bozzo, 2007). The concession will be granted for 30 years (with renewal privileges) and will be subject to more flexible norms than the ones applied to public telephone service concessions. However, long distance telecommunication services need a different type of concession and VoIP providers would need both. If the service does not intend to interconnect with the PSTN it will be classified as a complementary service and it will not be regulated.

A2.- Universal Service: The Telecommunication Development Fund (FDT) works in Chile to promote Universal Service, although there are no established rules that force operators to contribute to this fund. Service providers pay taxes and for the right to use the spectrum, if applicable. The money is transferred to the government and it is not used in any specific sector.

A3.- Numbering and Emergency Numbers: It is not yet defined, but the regulatory framework will establish a non geographical numbering plan, so that any user keeps the same phone number, regardless of the location. Telephone directory provision will not be mandatory.

A4.- Infrastructure: According to a study conducted by IDC Chile, this country has the highest broadband penetration in Latin America (Cisco Systems, 2006). Between March and June 2006, more than 100,000 high-speed Internet access lines were deployed and the connections in households grew $12 \%$. The nationwide broadband penetration rate by the end of 2006 was 6.8 per 100 inhabitants.

In April 2006, WIP Chile disclosed the results about Internet usage in Chile (WIP Chile, 2006). Around 40.2\% people used the Internet in 2006, while Internet access from home users grew from $21 \%$ to $28 \%$. People who used the Internet had a tendency to watch less TV or listen to the radio, and read more newspapers. In 2006, 28\% accessed the Internet from home, 18\% from work, $19 \%$ from school, $19 \%$ at a friend's house, $10 \%$ at free access places and $18 \%$ at paid access places. Figure 2 shows the percentage of Internet Access in 2006. 


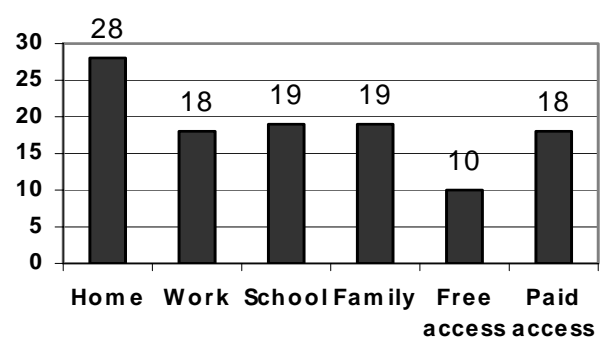

Figure 2: Percentage of Internet Access in 2006. Source: WIP Chile

The same WIP Chile report describes that people accessing Internet from home spent around 7.7 weekly hours online, while people accessing from schools spent 1.9 weekly hours, and people that access from their jobs spent around 3.7 weekly hours navigating.

In 2005 there were 211 telephone main lines, 172 Internet users and 141 personal computers per 1000 people (World Bank, 2005).

\subsubsection{Motivation}

\section{M1.- VoIP Market:}

In Chile, Telefónica CTC is the incumbent. RedVoiss, on the other hand, is one of the biggest residential and business market VoIP providers in Chile (RedVoiss). It offers good QoS and competitive tariffs. Communication between RedVoiss users is free, disregarding the user's location. Their service scheme is similar to others: the user needs broadband access and a softphone to communicate at the moment of using the PC. A traditional telephone adapter is also available.

M2.- Affordability: According to a survey (Planificación, 2006), the first decile has 1,2\% of the total income of the country, whereas decile number 10 has 38,6\%. In November 2006, this meant an average income of $\$ 16,84$ for decile 1 and $\$ 884,96$ for decile 10 .

According to the World Bank, the ICT expenditure in 2005 was 6.1 (\% of Gross Domestic Product) (World Bank, 2005).

M3.- Level of competition: Companies are migrating to VoIP due to its multiservice protocol characteristics. In 2005, RedVoiss decided to sue Telefónica CTC because it considered that Telefonica CTD had been blocking VoIP access to ISPs that run over a platform called Megavía. Megavía is a service that offers connection between the user and its ISP, using Telefónica's DSL networks. The ISP is in charge of delivering bandwidth to the user, not Telefónica. Telefónica was fined and was forced in 2006 to facilitate VoIP to their customers and stop blocking these services, after being proved that they were blocking VoIP development.

Table 4 shows a comparison of the telephone tariffs in Chile between the operator and the VoIP provider RedVoiss. 


\begin{tabular}{|l|l|l|}
\hline & \multicolumn{1}{|c|}{ RedVoiss (USD) } & \multicolumn{1}{|c|}{ Telefónica (USD) } \\
\hline Local calls (per minute) & 0.0295 & 0.03601134 \\
\hline Minute to Rome, Italy & 0.04 & 0.000372348 \\
\hline Minute to Lima, Peru & 0.05 & 0.000372348 \\
\hline
\end{tabular}

Table 4: Telephony Tariffs in Chile

\subsubsection{Analysis}

In Chile, a VoIP regulatory framework will probably be enacted soon. According to the VoIP services classification, it was determined to regulate only those services interconnecting with the PSTN. Interconnection between VoIP and PSTN operators will be mandatory. Several companies disagree with this proposal and with the fact that VoIP is considered a public telecommunication service and needs a license to operate. Numbering will provide users with a single telephone number and emergency services access will be mandatory. The incumbent does not offer VoIP. Even though Chile is the most advanced country in Latin America when it comes to regulation, the incumbent has no real motivation to offer VoIP services, since the incumbent would compete against itself. The incumbent operator could probably face a strong competition from VoIP operators. It is clear that the incumbent operator has the ability to deploy VoIP services. However, probably it is not strongly motivated because VoIP operators of the competition will offer more or less the same services that the incumbent is already offering through its PTSN network. Therefore, the incumbent is located in the fourth quadrant.

In this case it would be necessary to wait for the evolution of the market. If the incumbent is not interested in offering the VoIP technology and the operators from the competition offer VoIP, then there is a fair competition of technologies.

\subsection{Mexico}

Mexico's regulating agency is the Federal Telecommunications Commission, COFETEL, which is an independent agency of the Telecommunications and Transports Ministry (SCT). COFETEL was established in 1996, with the goal of defining technical plans and standards; promoting projects and human resources; issuing recommendations regarding licenses; planning of frequency spectrum and management of satellite communications; supervising interconnection and certain tariffs; and monitoring compliance of conditions established in the license titles (Diario Oficial de Mexico, 1996).

\subsubsection{Ability}

A1.- VoIP Regulatory Framework: There is no specific regulation for VoIP, although it is established that telephone services, whether they are local, national or international long distance, can only be provided by authorized operators with a concession. Local and long distance services are offered only by licensed companies, authorized by the SCT, based on the Federal Telecommunications Law (Jalife, 2004). 
Regarding IP, there are no standards, since the COFETEL promotes the users' rights to hire any service and subscribers can freely choose.

A2.- Universal Service: Even though there is not a concept in the traditional sense of "Universal Service Fund", there exists a "Telecom Social Coverage Fund", whose resources have come in the past from the government budget, but whose future is uncertain. Other than that, specific coverage and investment obligation are defined on a case-by-case basis, and established in each operators license title.

A3.- Numbering and Emergency Numbers: Since there is not a VoIP specific regulation, there is no numbering scheme for VoIP in Mexico and no emergency services offerings.

\section{A4.- Infrastructure:}

INEGI reported that $18.4 \%$ of households in Mexico had a PC (INEGI). According to the OECD (OECD), 8.9\% of households in Mexico had access to the Internet in 2005..

In 2005 there were 189 telephone main lines, 181 Internet users and 136 personal computers per 1000 people (World Bank, 2005).

\subsubsection{Motivation}

M1.- VoIP Market: Telmex is the incumbent operator in Mexico and is starting to offer VoIP in the business market. Some operators have been migrating their systems to IP based technologies, offering national and international long distance services. Even so, benefits offered by this technology make it worthy to offer the service. Telmex could easily dominate the market, since as of today it has hold of most broadband users in Mexico.

M2.- Affordability: According to the National Income and Expense Survey 2006, income for each decile was the following as shown in Table 5:

\begin{tabular}{|c|c|}
\hline Decile & 2005 (Mexican pesos) \\
\hline 1 & 1274.1 \\
\hline 2 & 2360.5 \\
\hline 3 & 3218.8 \\
\hline 4 & 4120.1 \\
\hline 5 & 5145.4 \\
\hline 6 & 6351.6 \\
\hline 7 & 7953.6 \\
\hline 8 & 10411.2 \\
\hline 9 & 14873.6 \\
\hline 10 & 40389.7 \\
\hline
\end{tabular}

Table 5: Income per capita in a quarter (2005). Source: INEGI, 2006

INEGI reports that the total household income grew by 3.9\% between 2000 and 2005 (INEGI). On the other hand, according to the World Bank, the ICT expenditure in 2005 was 3.3 (\% of Gross Domestic Product) (World Bank, 2005) 
M3.- Level of competition: Table 6 shows a comparison of the telephone tariffs in Mexico between the incumbent operator Telmex and the VoIP operators VoxIP, NetVoice and Masternet.

\begin{tabular}{|l|l|l|l|l|}
\hline & \multicolumn{1}{|c|}{ Telmex (USD) } & \multicolumn{1}{|c|}{ VoxIP (USD) } & NetVoice (USD) & Masternet (USD) \\
\hline $\begin{array}{l}\text { Local calls } \\
\text { (per minute) }\end{array}$ & 0.147738 & 0.0886374 & 0.101979 & $\begin{array}{l}20.3105 \\
\text { unlimited }\end{array}$ \\
\hline $\begin{array}{l}\text { Minute to } \\
\text { Rome, Italy }\end{array}$ & 0.509589 & 0.538915 & 0.509980 & 0.611976 \\
\hline $\begin{array}{l}\text { Minute to } \\
\text { Lima, Peru }\end{array}$ & 0.203835 & 0.606280 & 0.509980 & 0.611976 \\
\hline
\end{tabular}

Table 6: Telephony Tariffs in Mexico. Source: webpage of the companies

\subsubsection{Analysis}

The incumbent in Mexico is also in the fourth quadrant, lacking motivation. In this country it is illegal to offer any telecommunication service without the corresponding authorization or registration. Some operators are starting to offer VoIP for the business market, taking benefit from the services' growth in Mexico. Operators are not forced to offer emergency services or to contribute to Universal Service; they only cover their license commitment.

There are big companies that are offering residential and corporative VoIP services, but they can not compete with the incumbents' prices. to motivate them and generate movement towards the panacea quadrant, VoIP could be considered an emergent technology, e.g. QoS and Emergency numbers requirements should not be so strict.

\subsection{Peru}

Peru's regulating organism is the Private Investment in Telecommunications Supervising Organism (OSIPTEL). Its mission is to promote public telecommunication service development because they benefit society, promoting market competition and universal access to the telecommunication services, protecting user's rights. It is technically, economically and administratively independent from any other organism or agency.

\subsubsection{Ability}

A1.- VoIP Regulatory Framework: OSIPTEL considers VoIP to be a technology, not a telecommunication service, so it is not regulated (Regulatel, 2002). Public telephone service provision is allowed only after getting the corresponding license. Internet is considered a VAS, and since VoIP allows users to transmit information through the Internet, it receives the same treatment. This type of service is authorized by the Transport and Communications Ministry, and the technology used by each operator to provide the service is not taken into consideration.

OSIPTEL recognizes network neutrality, non-discrimination, free market access and competition to ensure equal rights amongst service providers. 
In January 2007, OSIPTEL stated that no operator was allowed to block or limit access to any applications that allow the use of VoIP (OSIPTEL). It is in constant revision of regulatory options, but is not prone to adopt norms that limit operator's capacity to compete against the incumbent, Telefónica. The policy consensus is that commercial exploitation of VoIP should be regulated, for calls that initiate or end in the PTN. In practice, there is no specific regulation regarding this. This approach provides a level of certainty to encourage new entrants to the market and also leaves room for further policies concerning VoIP. This is encouraging since VoIP allows for reduced costs for new long distance entrants. In some countries, regulation is based, for example, on the type of service or its quality. VoIP impacts universal service schemes, depending on how it is financed and defined and whether or not VoIP and conventional telephony are considered equivalent.

At present, ISPs do not need licenses; they only have to register at Transport and Communications Ministry. ISPs are classified as Value Added Services, so no foreign ownership limits apply.

The only law that applies to VoIP is Supreme Decree \#013-93-TCC, articles 3, 5 and 7, which state (OSIPTEL):

Article \#3. - Every person has the right to provide or use telecommunication services in the way stated by regulatory dispositions of the sector.

* Article \#5. - Telecommunications are provided under fairness principle, promoting integration of the entire territory.

* Article \#7. - Network interconnection and public telecommunication services are matters of public and social interest.

A2.- Universal Service: The FITEL (Investment in Telecommunications Fund) in Peru is in charge of financing telecommunication services provision in rural areas (OSIPTEL), promoting participation of private companies. OSIPTEL is in charge of managing the fund and assigning the resources efficiently. FITEL collects resources from service operators, who have to cooperate with $1 \%$ of their annual revenues (OSIPTEL), apart from what is collected from fees charged when the operator does not meet QoS requirements, as the Telecommunications Law (Cisco Systems, 2006) establishes.

A3.- Numbering and Emergency Numbers: There is no numbering scheme defined for VoIP. There is no emergency services policy for VoIP.

A4.- Infrastructure: Cisco's Broadband Barometer in Peru showed that broadband grew 37,5\% in 2006 and had an overall penetration of 1,9\% (Cisco Systems, 2006). In the entire country, the total number of connections grew 47\%. OSIPTEL has the results (OSIPTEL, 2006) of broadband users in 2006, establishing substantial growth of 460,000 users for that year. VoIP penetration was around $12 \%$.

In 2005 there were 80 telephone main lines, 164 Internet users and 100 personal computers per 1000 people (World Bank, 2005). 


\subsubsection{Motivation}

M1.- VoIP Market: The incumbent, Telefónica Peru, is starting to offer residential VoIP services. Other companies offer VoIP, even though there is no service regulation, because it is profitable.

M2.- Affordability: According to CEPAL for 2004 income distribution in homes is as described in Table 7.

\begin{tabular}{|c|c|c|c|}
\hline Poorer (40\%) & Poor (30\%) & Rich (20\%) & Richer (10\%) \\
\hline $15.4 \%$ & $24.6 \%$ & $27.4 \%$ & $32.6 \%$ \\
\hline
\end{tabular}

Table 7: Source: Programa social de América Latina 2006, Pobreza y distribución del ingreso, CEPAL

According to the World Bank, the ICT expenditure in 2005 was 6.6 (\% of Gross Domestic Product) (World Bank, 2005).

M3.- Level of competition: The incumbent offers VoIP basically in the business sector.

\subsubsection{Analysis}

In Peru VoIP services are not regulated, since they are considered value added services. The incumbent operator Telefonica has the ability to deploy the VoIP technology, but it is not motivated to offer this technology.

Maybe it could be convenient to offer incentives so that other operators could deploy VoIP services, specially in rural areas. These incentives would consist in a more easy deployment of a VoIP system: the QoS of the voice should not be so strict as the quality of the voice in a PSTN network and the emergency numbers should not be mandatory at all the locations.

In can be concluded that the incumbent operator in Peru is in the fourth quadrant, with resources but no motivation.

\subsection{Similarities and Differences}

After analyzing the five countries, it is possible to locate each one in the motibility framework. Just for illustrative purposes the relative position of every country is shown in Figure 3. The similarities and differences between the countries are described below. 


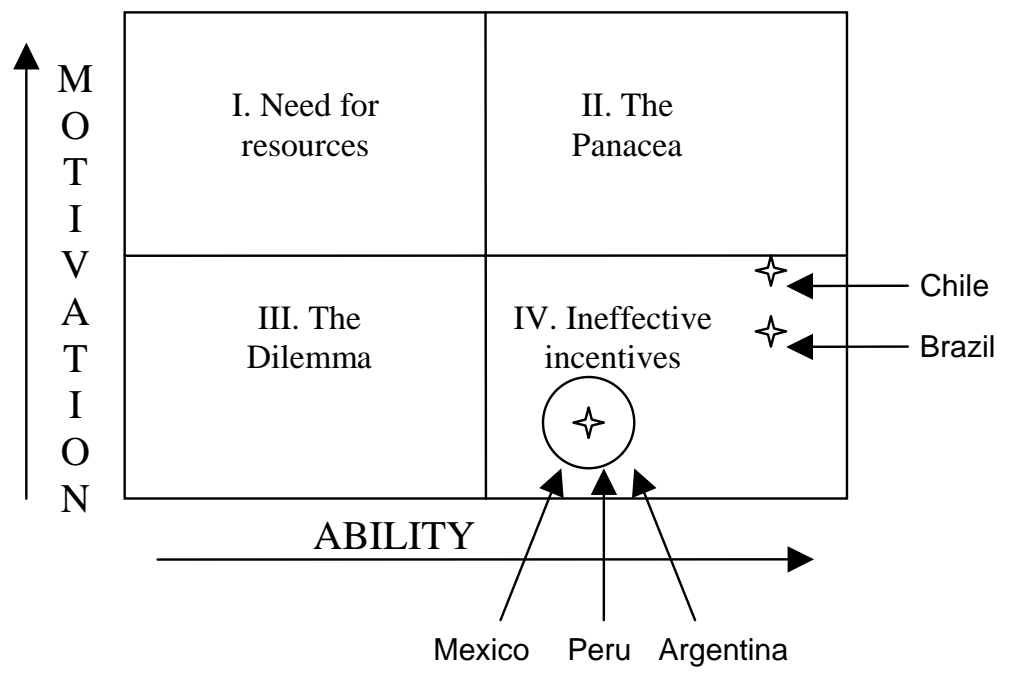

Figure 3: Location of every country in the Motibility framework

\section{Similarities:}

1. The five countries are located in the ineffective incentives quadrant. In every case, incumbent companies lack motivation to offer VoIP services, since they have already deployed a circuit-switched network to offer the voice service, and it is not clear whether it is profitable for them to offer VoIP services at this point in time.

2. In the studied countries VoIP services require a license or concession to be offered.

3. No country has established yet a specific numbering VoIP scheme.

\section{Differences:}

1. Chile is the only one of the five countries in which a specific VoIP regulatory process is taking place, specifically for the type of VoIP service that interconnects with the PSTN and that will be treated as a telecommunication service.

2. Unlike Brazil and Chile, where different VoIP types are considered, in Argentina, Mexico and Peru no VoIP types were defined. Brazil and Chile present VoIP classification in the following three types:

a. VoIP that does not interconnect to the PSTN, calls are originated and finished in a PC. This type is not regulated in both countries.

b. Restricted VoIP, used in corporate networks, isolated from other telecommunication services. Brazil requires a license to operate, whereas in Chile it is not regulated.

c. VoIP that interconnects to the PSTN, for which is necessary a concession. Regulators in Chile pretend to create a different license for traditional telephony services, in order to have more flexibility. Long distance operators would need to obtain two licenses. 


\section{Conclusions and Recommendations}

In this paper the Motibility Framework was applied to understand the position of incumbent operators regarding the use of VoIP in Latin America. The VoIP market in Latin America is developing. The Motibility framework does not pretend to be a unique solution to the regulatory problem, nor a recipe that applies in the same way to different cases, but a guide to identify the the main problems and offer solutions to achieve results. It was found that in all the countries studied the incumbent operators do not have a great motivation to offer VoIP services because their business model is based on their already deployed circuit-switched telephony network.

Of the five countries studied, Chile is ahead, following a process that started in 2004. Chile's regulatory proposal could probably be ready by the end of 2007. Chile is followed by Brazil. Brazil is not in the process of defining any specific regulation for VoIP, but they have a service classification and impose obligations to those interconnected to the PSTN, by means of a license. Argentina, Mexico and Peru have a similar case: a license is needed in order to offer VoIP services but apart from this legal aspect, the governmental institutions do not seem to do nothing to promote the deployment of VoIP. In Argentina, no attempt to regulate VoIP has been done. It is required that operators obtain a license to provide the service, so it is assumed that every communication service obligations will be met. Peru's situation is similar since they only need a concession to offer the service, and there is no specific regulation towards it. It might be possible that if Latin American countries do not define a regulatory framework on time, companies will lose revenues and the possibility to create innovative processes.

If the governmental institutions would be motivated to promote the deployment of VoIP, they could classify it as an emergent technology. There are a few points that could be defined by the government or the telecom regulator: A numbering plan could be defined that takes into account the location particularities of the VoIP system, because VoIP users are not always located in the same physical place. The numbering plan could also consider the current technical difficulties of offering emergency numbers through a VoIP system. Moreover, interconnection aspects should be defined so that VoIP operators do not have limitations at the moment of interconnecting their networks with data or PSTN networks. On the other hand, in rural areas with energy limitations it is difficult to offer a telecommunications service that can work 24 hours per day. Perhaps in these areas telephony operators could be allowed to offer a telephony service with different quality requirements. Thereby, VoIP services could also be used in these zones.

Nowadays many users are working with telecommunications services that are based on IP technologies. Over time incumbents will have to migrate completely to IP-based technologies. The question is when they will take this decision so that their current business models, in many cases based on their already deployed circuit-switching voice networks, are not threatened. 


\section{References}

Afuah, A., \& Tucci, C. L. (2003). A model of the Internet as creative destroyer. IEEE Transactions on Engineering Management , 50 (4), 395.

Anthony, S. R. (2002). The Policymaker's Dilemma: The Impact of Government Intervention on Innovation in the Telecommunications Industry. http://www.signallake.com/innovation/The_Policymaker's_Dilemma.pdf

Bozzo, I. (April 2007). CONADECUS Chile. Telefonía IP en Chile, Marco regulatorio y una mirada a la experiencia internacional: http://www.conadecus.cl/

CEPAL. (2006). Programa Social de América Latina. Proporción de domicilios con acceso a Internet: http://www.eclac.cl/publicaciones/xml/0/27480/PSE2006_Cap1_Pobreza.pdf

CGI. (2006). Domicilios y Usuarios. Proporción de domicilios con acceso a Internet: http://www.cetic.br/usuarios/tic/2006/rel-geral-05.htm

Christensen, C. (2000). The Innovator's Dilemma: The Revolutionary Book that Will Change the Way You Do Business. New York, N.Y.: Harper Business.

Cisco Systems. Redacción Virtual.

http://www.ciscoredaccionvirtual.com/redaccion/comunicados/

Cisco Systems. (2006). Redacción Virtual. http://www.redaccionvirtual.com/redaccion/

Comisión Nacional de Comunicaciones. (September 2000). Decreto 764/2000. http://www.cnc.gov.ar/normativa/pdf/dec0764_00.pdf

Comisión Nacional de Comunicaciones. (s.f.). Ley Nacional de Comunicaciones. http://www.cnc.gov.ar/cit/TextoNorma.asp?ID=76

Comunicaciones, I. d. (s.f.).

Diario Oficial de Mexico (1996). "Decreto por el que se crea la Comisión Federal de Telecomunicaciones", Diario Oficial, August 9, 1996.

INDEC. (2007). Estimador Mensual de Actividad Económica. http://www.indec.gov.ar/nuevaweb/cuadros/17/esti_eco_06_07.pdf

INEGI, "Encuesta Nacional sobre Disponibilidad y Uso de las Technologies de la Información en los Hogares". 2005.

ITEL Chile, S.A. (2007). Respuesta a Consulta Pública. http://www.subtel.cl/

Jalife, S. (2004). Voz sobre IP y temas afines. COFETEL: http://www.cft.gob.mx/cofetel/presentaciones/041112VOZ.ppt

Kourkoupa, P. (2006). Global Crossing. IP Convergence: Beyond VoIP, Beyond Cost Savings: http://blogs.globalcrossing.com/node/167

Mueller, M. (1999). EMERGING INTERNET INFRASTRUCTURES WORLDWIDE (Introduction to special section) (Industry Trend or Event) (Editorial). Communications of the ACM, 42(6) , 28.

OECD, OECD Information Technology Outlook 2004.

OSIPTEL. http://www.osiptel.gob.pe/store/documentos/noticias/20684.htm

OSIPTEL. (2006). El sector de telecomunicaciones a diciembre del 2006. http://www.osiptel.gob.pe/

OSIPTEL. Estudios de Telecomunicaciones. Acceso Universal y la Política de FITEL: http://www.osiptel.gob.pe/

OSIPTEL. Política y Estrategia. http://www.osiptel.gob.pe/

OSIPTEL. Texto único ordenado de la Ley de Telecomunicaciones. Decreto Supremo No. 1393-TCC: http://www.osiptel.gob.pe/ 
Planificación, M. d. (2006). Encuesta de caracterización socioeconómica nacional. http://www.mideplan.cl/

RedVoiss. (s.f.). RedVoiss Telefonía Internet. www.redvoiss.net

Regulatel. (October 2002). Presidencia de Regulatel 2001-2002. Boletín No. 4: http://www.regulatel.org/publica/boletin02.htm

SUBTEL. (December 2006). Consulta Pública: Reglamento de Servicio Público de Voz sobre Internet. http://www.subtel.cl/

Swain, W. (2006). VoIP is the new reality in Latin America, The Yankee Group, 2006. http://www.yankeegroup.com

Takahashi, A., \& Yoshino, H. (2004). Perceptual QoS assessment technologies for VoIP.(quality of service)(voice over internet protocol). IEEE Communications Magazine, 42(7) , págs. 28-34.

Telecommunity. (2007). http://www.telcommunity.com/visor.php?id_noticia=20844

Thomsen, G., \& Jani, Y. (2000). Internet Telephony: Going like crazy. IEEE Spectrum, 35 (7) , pág. 52.

Trope, K. (2005). Novo Law Group. VoIP Regulation in the Americas: http://www.novolaw.com/pdf/voip-americas.pdf

Vaida, B. (2004). A dream come true for telecom lobbyists. National Journal, 36(12) , 894-895.

VoIP Subscribers (Fast Facts)(Brief Article). (2005). Journal of Property Management, 70(3) , 9.

Webpolygone. (s.f.). http://www.webpolygone.net/imagenes/infant/infant.htm

Werbach, K. (2005). Using VoIP to compete. (Frontiers) (voice over Internet Protocol). Harvard Business Review.

Weyer, M. (2005). A radical change in the relative value of everyday things. (ANY OTHER BUSINESS)(Skype Technologies S.A.). Spectactor , 299 (94246), 30.

WIP Chile (2006), World Internet Project (WIP) Chile 2006 Survey, http://www.wipchile.cl/

World Bank. (2005). World Bank Statistics. ICT at a Glance. 